\title{
Human Capital Accumulation and Entrepreneurial Spirit of Migrants Returns in Cilacap Regency, Central Java Province
}

\author{
Suyanto Suyanto ${ }^{1^{*}}$, Fajrul Falah ${ }^{2}$ \\ ${ }^{1}$ Social Anthropology Department, Diponegoro University Semarang, Indonesia \\ ${ }^{2}$ Literature Department, Diponegoro University Semarang, Indonesia
}

\begin{abstract}
Returning migrants generally have a high dependence on working abroad because remittances are used for consumptive and investment needs. Therefore, it is necessary to explore the accumulation of human capital and its entrepreneurial spirit. Because of that, the purpose of this study is to explain the influence of social demographic factors of returning migrants in improving their household welfare and to explain the use of human capital and entrepreneurial spirit of migrants return to improving household welfare. This study used survey and case studies design. The research was conducted in Cilacap Regency. The sample size was determined using the Krejcie and Morgan technique. Data collection used structured interviews, in-depth interviews, and focus group discussions. Data analysis used descriptive statistical analysis, single frequency distribution table and qualitative descriptive analysis. The results of the study show that migrants return to accumulate human capital (knowledge, skills, and technology in agriculture and domestic work, skills in using foreign languages, use of free time for online business, and recreational habits on holidays. In general, returning migrants have a high entrepreneurial spirit, mainly in the form of innovation, the courage to take risks, perceptions of opportunities, and intuition related to entrepreneurship.
\end{abstract}

\section{Introduction}

Various studies show that migrants in general and returning migrants, in particular, have accumulated human capital, which is useful in economic development, both at a macro scale (regional and national) $[1,2]$ and household [3,4,5]. Previous studies have shown that returning migrants, especially international migrants, are kind of "addicted" to always working abroad in the Indonesian context. This is more due to remittances, which tend to be for consumptive and investment needs $[6,7,3]$. In addition, after becoming international migrants, they became generous in shopping and a changed lifestyle than before working abroad. Within a few months in Indonesia, they had run out of money. In these conditions, they have no other choice but to go abroad again as migrants. This kind of condition occurs

*Corresponding author: suyanto@live.undip.ac.id 
almost repeatedly for the majority of return migrants [6,7]. This kind of phenomenon occurs in areas of origin of pockets of migrants in Indonesia, such as NTT, NTB and Baweyan (East Java) [8], Cilacap (Central Java) [6]. Cilacap is the largest sending area for international migrants in Central Java from year to year [9]. In this regard, Cilacap was chosen to be the sample for this study area.

The main driving factor for migrants to return to work abroad is economic problems, namely very limited job opportunities and low income in the country of origin (Indonesia) and wide employment opportunities and a higher level of income in the destination country [8]. Even the findings of Haris [7] show that becoming an international migrant or, according to Law No. $18 / 2017$ as an Indonesian migrant worker (IMW))[10] is a strategy to survive for migrants and their families. Ideally, they (return migrants) work abroad to earn income (remittances) which can be used not just as a survival strategy or meeting consumptive needs but can remain economically active in their home country by using remittances (social, economic and human capital) that have been obtained abroad. This is in line with the findings of Maria, Kazuhito, and Ibourk [11,12,13] that migrants bring back various abilities in the form of human capital in the form of skills acquired while working abroad and also remittances that can be used to improve home welfare stairs and development in the area of origin [1].

However, several studies have shown that the ability to return migrants can not be fully utilized in productive behaviour in the area of origin. This is due to the very limited employment opportunities in the area of origin and the mindset of returning migrants who do not have a plan of what to do after they are no longer migrants [14]. This should require serious attention and handling from the government to not increase the number of unemployed people when they return to Indonesia. Therefore, human capital is an important instrument in empowering returning migrants to improve their household welfare. However, no previous studies have focused on exploiting the accumulated human capital and exploring the entrepreneurial spirit of migrants again. Because of this, this study focuses on the accumulation of human capital and the entrepreneurial spirit of migrants in improving household welfare.

Based on the background of these problems, the objectives of this study are: (1) To explain the influence of social demographic factors of returning migrants in improving household welfare; (2) explaining the use of migrant human capital again in improving household welfare, and entrepreneurship spirit of return migrants to improve the welfare of their households.

\section{Theoretical Framework}

\subsection{Human Capital}

In simple terms, human capital is the accumulation of knowledge, expertise, abilities, and skills that make humans an asset or capital. Human capital is the accumulation of knowledge, expertise, experience, and other attributes of workers' strengths in an organization and stimulates productivity, performance, and achievement of strategic goals. Thus, all components of human capital will still be able to be used again by the organization (business and social) when someone is no longer working (retired) [15]. In migration, human capital includes age, education, skills and work experience, and proficiency. In the United States, the human capital variable has a much larger positive effect on the wages of foreign workers than does the social capital variable. Conversely, so human capital significantly increases workers' wages in Japan, whereas human capital does not [16]. Human capital is accumulated through the time spent learning new skills on or off the job. There is a trade-off between current income and potential future gains due 
to investment in human capital [5]. Experienced international return migrants accumulate human capital for the sending country [1,5]. Thus, on a micro-level, the human capital savings of migrants return to provide economic benefits for them in the area of origin [17]. Returning migrants with quality human capital bring several capitals, namely financial capital, social capital, leadership, and training [3].

In the context of entrepreneurship, Verheul [18] explained that someone with high ADHD-like behaviour tends to have high entrepreneurial intentions. ADHD (Attention Deficit and Hyperactivity Disorder) is a symptom/deviation in inattention and hyperactivity related to job choices and performance. In various studies, as pointed out by Baron (1998); Allison et al. (2000); Stewart and Roth (2001); Astebro and Thompson (2011) [18] explain that entrepreneurs and non-entrepreneurs differ in characteristics: cognitive bias, risk-taking tendency, ADHD-like behaviour, feelings for variation, intuition. Meanwhile, the classical theory, as explained by Knight (1921), Scumpeter (1934), and Kirzner (1979), states that the characteristics of entrepreneurs are having a spirit of innovation, perception of opportunities, and handling of uncertainty (innovation, opportunity perception, and handling uncertainty) [18]. In addition, the entrepreneurial spirit includes the desire to be independent, take risks, learn from experience, competitive attitudes, motivation, work hard, believe in yourself, drive for achievement, dislike helping hands or help from others, never giving up and depending on another [19]. In this study, the entrepreneurial spirit includes innovation, courage to take risks, perception of opportunities, and intuition related to entrepreneurship.

\section{Research Method}

This research used a survey design and case studies. Spatially, Cilacap Regency was chosen as the location of this research based on the following considerations: (1) Cilacap Regency is the area of origin of international migrants nationally; (2) returning migrants to Cilacap is highly dependent on working abroad; and (3) because of the large number of productive age population working abroad in this district, the number of remittances is also large. The study sample size was determined using the Krejcie and Morgan technique [20]. Data collection used structured interviews (questionnaires) [21], in-depth interviews, and focus group discussions [22]. Data analysis used descriptive statistical analysis, single frequency distribution table and qualitative descriptive analysis.

\section{Results and Discussion}

\subsection{Characteristic of Respondents}

Respondents to the study of returning migrants were 157 people consisting of 122 women or $77.7 \%$ men and 35 men or $22.3 \%$. This situation is a common symptom, including in Cilacap District, that migrants are women. This is because many job opportunities abroad are reserved for women, namely jobs in the domestic sector. Meanwhile, employment opportunities for male workers, namely the plantation, industry and building sectors, have more limited absorption capacity than the domestic sector.

The data in (Table 1) shows that the most PMI numbers are at the early age of having a family. Why is the largest number of returning migrants aged 31-40 years. Returning migrants generally work abroad to improve their lives after returning from abroad..

Table 1. Ages of Respondent. Source: Primary Data 2021. 


\begin{tabular}{|c|c|c|}
\hline Age & Number & Percent \\
\hline$\leq 20$ & 1 & 0.6 \\
\hline $21-30$ & 43 & 27.4 \\
\hline $31-40$ & 71 & 45.2 \\
\hline $41-50$ & 30 & 19.1 \\
\hline $51-60$ & 12 & 7.6 \\
\hline Total & 157 & 100 \\
\hline
\end{tabular}

Table 2 indicates that employment opportunities in various receiving countries from Indonesia is in the work sector that relies more on simple labour and skills, such as industrial plantations, forest and plantation product management, and domestic help for low-educated workers. . Generally, these jobs are not in demand by host country citizens because the salaries are too low. However, this is an opportunity for Indonesian workers to get a much higher and continuous income than working in a home country.

Table 2. Respondents by Education Level. Source: Primary Data 2021.

\begin{tabular}{|c|c|c|}
\hline Education level & Number & Percent \\
\hline Not finish Elementary School (ES) & 13 & 4.5 \\
\hline ES & 94 & 29.9 \\
\hline Yunior School (YC) & 134 & 42.7 \\
\hline Senior School (SC) & 70 & 22.3 \\
\hline Bachelor & 2 & 0.6 \\
\hline Total & 157 & 100 \\
\hline
\end{tabular}

\subsection{Human Capital Accumulation of Return Migrants}

Most of the migrants return to acquire practical work skills when they return to their countries of origin. This is also in line with previous studies that return migrants have accumulated human capital, which is beneficial for sending countries [1]. In addition, working abroad can increase income and change traditional mindsets to modern ones [3]. Thus, the accumulation of migrant human capital again provides economic benefits for him in the country of origin [17]. In addition, returning migrants also bring other capital, financial capital, social capital, leadership, and training [11, 12, 13].

Table 3. Knowledge Acquired by PMI in Host Countries. Source: Primary data 2021.

\begin{tabular}{|c|c|c|}
\hline $\begin{array}{c}\text { Knowledge or Experience Gained in } \\
\text { the Country of Work }\end{array}$ & Number & Percent \\
\hline Yes & 119 & 75.8 \\
\hline None & 36 & 22.9 \\
\hline No answer & 2 & 1.3 \\
\hline Total & 157 & 100 \\
\hline
\end{tabular}

Knowledge, experience, and skills acquired by migrants in the host country include foreign language skills and skills to operate work tools. (Table 4) shows that $39 \%$ of migrants have returned to acquire skills to operate technology-based work tools. The various knowledge or experiences and skills acquired in the host country are described below.

Table 4. Knowledge Acquired by PMI in Host Countries. Source: Primary data 2021. 


\begin{tabular}{|c|c|c|}
\hline $\begin{array}{c}\text { Knowledge or Experience Gained in } \\
\text { the Country of Work }\end{array}$ & Number & Percent \\
\hline $\begin{array}{c}\text { Techniques or Technology or Work } \\
\text { Tools }\end{array}$ & 61 & 38.9 \\
\hline Shopping in Modern Markets & 10 & 6.4 \\
\hline Eating at Restaurants or in the Mall & 3 & 1.9 \\
\hline Picnic Habits on Holidays & 14 & 8.9 \\
\hline No Answer & 35 & 22.3 \\
\hline Others & 34 & 21.7 \\
\hline Total & 157 & 100 \\
\hline
\end{tabular}

(Table 5) describes the technology migrants get back when working in host countries, namely operating work equipment in households $(45 \%)$, such as vacuum cleaners, washing machines, dishwasher, etc. -Cookingsuch as ovens and electric stoves, microwave tools, coffee makers, and so on. In addition, returning migrants can process forest products such as wood, rattan and plantation products.

Table 5. Techniques or technology obtained from abroad. Source: Primary Data 2021.

\begin{tabular}{|c|c|c|}
\hline Technique or technology obtained & Jumlah & Persen \\
\hline Processing of forest products (wood, rattan and others) & 4 & 4.7 \\
\hline Management of agricultural / garden land & 3 & 3.5 \\
\hline $\begin{array}{c}\text { Processing of plantation products (vegetables, oil palm and } \\
\text { industrial plants) }\end{array}$ & 3 & 3.5 \\
\hline Household work tools (floor cleaning equipment, stove ) & 39 & 45.3 \\
\hline $\begin{array}{c}\text { Working equipment in the household (floor cleaning } \\
\text { equipment, stove) }\end{array}$ & 1 & 1.2 \\
\hline Others & 36 & 41.9 \\
\hline Total & 86 & 100 \\
\hline
\end{tabular}

\subsection{Entrepreneurial Spirit of Returning Migrants}

Data shows that some returning migrants in Cilacap have a good spirit of innovation, starting from business desire related to skills acquired in the host country, developing existing businesses, online marketing, product packaging, as did Lamenas (39 years), Warti-Rino (40 years), Ratio (40 years), who are in the western food business respectively (pizza, bread and fish catches, shrimp and refill water). In addition, a migrant returns (Zanto, 41 years) have Alfamart in Jetis village, Nusawungu sub-district and other migrants (Rasurman, 41 years) are entrepreneurs working on shrimp ponds in Banjarasari, Karangpakis, and Karangtawang villages (Nusawungu sub-District) Regarding the courage to take risks, generally, migrants return to have this soul. Mentioned above has this soul. Rasurman and Ratio, for example, have high courage to take risks with their respective businesses preparing shrimp pond land and as a shrimp farmer who has not necessarily sold the pond that has been prepared and shrimp pond cultivation also often faces risks. However, until now, the business he does is still ongoing. Return migrants also generally have a good perception of reading business opportunities. By changing the lifestyle of the migrant community back to urban values, they are taking advantage of each other's opportunities for entrepreneurship. Wanagu (38 years), Warti-Rino, for example, the 
increasing number of people consuming non-rice food, such as rot, are in the bread business because in yearly events, weddings and events that gather mass, in the Cilacap area it has now started-using bread. Likewise, many residents are reluctant about daily drinks or do not have time to boil water, so Rasito uses it for the water refill business. In addition, their business intuition is generally alive, such as Suwarso and Wasis, migrants returning from Malaysia when in the village where ornamental plants are booming, they trade ornamental plants and cultivate ornamental plants with high economic value as cycads, palms and others.

\section{Conclusion}

Migrants are again accumulating human capital in terms of new knowledge and skills in operating technology for domestic work, forest product processing, and agriculture. Technology in agriculture includes technology for processing agricultural land and plantation products and processing forest products that account for nearly $40 \%$. In addition, returning migrants have adopted urban values of recreation on holidays and shopping. About $60 \%$ of returning migrants apply their experience and skills acquired abroad to jobs in Indonesia; the rest do not apply them. Return migrants who do not apply their skills to jobs in Indonesia are because daily work in the host country and Indonesia is not the same, the price of the equipment is too high in Indonesia for them, and the equipment does not exist in Indonesia.

Almost $78 \%$ of the returning migrants in Cilacap are women. This is because job opportunities in various host countries, especially Southeast Asia (Malaysia and Singapore), East Asia (Taiwan and Hong Kong), and the Middle East, are jobs in the domestic sector (households) and some work in the plantation sector (vegetables, crops) also for the female workforce. Meanwhile, men filled opportunities for work in the plantation (palm oil), industry and building sectors (Korea and Japan). In general, returning migrants have a high entrepreneurial spirit, such as innovation, courage to take risks, perception of opportunities, and intuition related to entrepreneurship.

This article is part of the Research Report for "Riset Penerapan dan Pengembangan (Development and Implementation Research)" which is funded by the Diponegoro University State Budget (APBN) for 2021, Contract No: 185- 15 / UN7.6.1 / PP / 2021.

\section{References}

1. C. Dustmann, I. Fadlon, Y. Weiss, Return Migration, Human Capital Accumulation and The Brain Drain, Jour of DE, 95 (2011)

2. K. Tipayalai, Impact of international labor migration on regional economic growth in Thailand, Jour of E Str, 9, 15 (2020)

3. Trisnaningsih, . Disertasi Ilmu Kependudukan, Sekolah Pascasarjana Universitas Gadjah Mada, Yogyakarta (2013)

4. J. Lara, International Migration and Human Capital in Mexico: Networks or Parental Absence?, Int J of E D, 41, 131-142 (2015)

5. K. Abdulla, Human Capital Accumulation: Evidence from Immigrants in Low-income Countries, Jour of C E. in press (2020)

6. Suyanto, Muzakka, Peran dan Kemandirian Tenaga Kerja Wanita dalam Rumah Tangga: Studi Kasus Tenaga Kerja Wanita Desa Penanggulan Kecamatan Pegandon Kab.Kendal, Laporan Penelitian Kajian Wanita Lemlit Undip (2002) 
7. A. Haris, N. Adika, Dinamika Kependudukan dan Pembangunan di Indonesia: Dari Perspektif Makro ke Realitas Mikro, LESF I (2002)

8. I. B. Mantra, Mobilitas Tenaga Kerja Indonesia ke Malaysia: Studi Kasus Flores Timur, Lombok Tengah, Pulau Bawean, Pusat Penelitian Kependudukan Universitas Gadjah Mada (1999)

9. Badan Pusat Statistik, Jawa Tengah dalam Angka 2019, Badan Pusat Statistik Semarang (2020)

10. UU No. 18/2017, Perlindungan Pekerja Migran Indonesia (2017)

11. C. D. Maria, P. Stryszowski, Migration, human capital accumulation and economic developmen, Jour of Dev E, 90 (2009)

12. K. Higa, R. Nonaka, T. Tsurumi, S. Managi, et al, Migration and human capital: Evidence from japan, The Jour J and Int Ec, 54 (2019)

13. A. Ibourk, Impact of Migrant Remittances on Economic Empowerment of Women: A Macroeconomic Investigation, Int Jour of Ec and Fin Iss, 4(3), 597-611 (2014)

14. Suyanto, Pemanfaatan Remitan Ekonomi dan Ketergantungan Migran Kembali Bekerja di Luar Negeri, End, 2 (2018)

15. C. J. L. Gaol, Human Capital: Konsep, Teori, Pengembangan dalam Konteks Organisasi Publik dan Bisnis, Grasindo (2015)

16. W.A. Cornelius, T.Tsuda, Z. Valdez, Human Capital versus Social Capital: A Comparative Analysis of Immigrant Wages and Labor Market Incorporation in Japan and the United States, Mig Inter, 2 (1) (2003)

17. O. S. Oladipo, Migrant workers' remittance and economic growth: A time analysis series, Jour. E D A, 54, 5 (2020)

18. I. Verheul et al., Sma. Bus. Ec., 45 (1), 85-101 (June 2015)

19. N. N. Jaya and I G.M. Subrata, Gan S, 8, 2 (September 2014)

20. B. M. Ida, Langkah-Langkah Penelitian Survai Usulan Penelitian dan Laporan Penelitian, Badan Penerbit Fakultas Geografi UGM (2000)

21. M.Singarimbun, S. Effendi, Metode Penelitian Survai, LP3ES (1995)

22. Sugiyono, Metode Penelitian Bisnis, Alfabeta (2012) 